
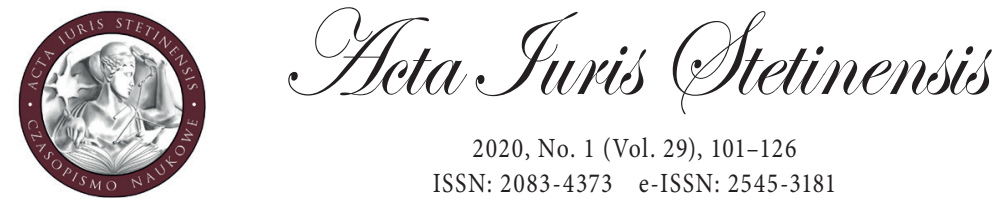

2020, No. 1 (Vol. 29), 101-126

ISSN: 2083-4373 e-ISSN: 2545-3181

DOI: $10.18276 /$ ais.2020.29-08

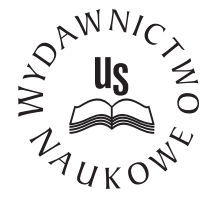

Piotr Majer

Assoc. Prof.

Pontifical University of John Paul II in Krakow, Poland

Faculty of Canon Law

e-mail: piotr.majer@upjp2.edu.pl

open Access

ORCID ID: 0000-0002-9516-8839

\title{
The lifting of "pontifical secrecy" and the relationship between the state and Church systems of justice in the subject matter of sex offences against minors ${ }^{1}$
}

\begin{abstract}
The article describes the issue of the relationship between the Catholic Church's judicial system and the national law enforcement authorities and judiciary powers after 6 December 2019, when Pope Francis lifted the so-called "pontifical secrecy" concerning canon criminal cases of clerics accused of sexually abusing minors. After a brief outline of the regulations referring to the institution of secrecy in the canonical legal order and arguments justifying the need to keep it, the author presents certain provisions on pontifical secrecy and the consequences of lifting it for the relationship between the state and the Church's system of justice.
\end{abstract}

Keywords: canon law, Catholic Church, canonical procedure, sexual abuse of minors, secrecy, pontifical secrecy, collaboration with civil authorities

1 The article was written as part of the research project No. 2019/33/B/HS5/02465, financed by the National Science Centre, Poland. 


\section{Introduction}

According to the rescriptum ex audientia pontificia of 6 December $2019,{ }^{2}$ Pope Francis lifted the 'pontifical secrecy' (secretum pontificium) for sexual abuse cases against minors, which are prosecuted under canon law (regardless of the activities of secular law enforcement and judicial authorities). The fact that the pontifical secrecy rule remained in force with respect to such offences was subject to criticism. Being bound by the pontifical secrecy rule, the authorities that conducted canonical criminal proceedings could not provide any information obtained in such proceedings to the law enforcement authorities without breaching the law of the Catholic Church. Such refusal was often treated as placing the Church above the law, or worse - an attempt to hide the offenders.

\section{The function of 'secrecy' in canon law}

It is not always mandatory to disclose, either verbally or in writing, one's own thoughts, actions, or knowledge. Both moral principles and laws stipulate that in justified cases, it is fair and even obligatory to stay silent, keep discrete, i.e. keep secrecy - either with respect to all or only to some unauthorised people. Secrecy as an object refers to the information that should remain hidden, while secrecy in a subjective sense refers to the obligation to refrain from disclosing any content subject to secrecy. ${ }^{3}$

The obligation to keep secrecy in the religious and Church context is particularly significant due to the relationship of trust between the people responsible for clerical and moral matters, who are often the subject of mutual contact within the Church community. Undoubtedly, the spiritual realm, human conscience, faith, prayers, and religious experiences are areas of intimacy and privacy, which deserve discretion and protection.

At this point, the moral teachings of the Church regarding the issue of discretion and the obligation to keep secrecy and the classification introduced thereby shall be omitted ${ }^{4}$ from this article so that the main focus is on secrecy as a legal category.

2 Secretary of State, Rescriptum ex audientia Ss.mi, 6.12.2019, "L'Osservatore Romano", 18.12.2019, p. 5.

3 See: Palazzini, P., Secretum, in: Palazzini, P. (ed.), Dictionarium morale et canonicum, Vol. IV, Roma 1968, p. 246.

4 The dictionary definition can be found in: Padovese, L., Segreto, in: Compagnoni, F. et al. (eds.), Nuovo dizionario di teologia morale, Cinisello Balsamo 1990, pp. 1205-1212. 
The Code of Canon Law ${ }^{5}$ - the fundamental Act of the Catholic Church, together with the Code of Canons of the Eastern Churches ${ }^{6}$ - including provisions which, together with other acts of laws from outside the Code, constitute one legal regulation of secrecy in the canonical legal order. Therefore, it is essential to first outline such provisions that create a catalogue of secrets protected under canon law. ${ }^{7}$

The most recognised and widely discussed rule is the secret of confession, i.e. sacramentale sigillum - which literally means the "seal of confession." In compliance with can. $983 \$ 1$ of the 1983 Code of Canon Law (CIC) and its corresponding can. $733 \S 1$ of the 1990 Code of Canons of the Eastern Churches (CCEO), "the sacramental seal is inviolable; therefore it is absolutely forbidden for a confessor to betray in any way a penitent in words or in any manner and for any reason." Other provisions included in the canon law (both Latin and Oriental Codes) also refer to the seal of confession: can. $983 \$ 2$ CIC and can. $733 \$ 2$ CCEO stipulate that "the interpreter, if there is one, and all others who in any way have knowledge of sins from confession are also obliged to observe secrecy." Furthermore, according to can. $984 \S 1$ of CIC and can. $734 \S 1$, "a confessor is prohibited completely from using knowledge acquired from confession to the detriment of the penitent even when any danger of revelation is excluded."

Nevertheless, the obligation of secrecy and discretion in the Catholic Church is much broader than the seal of confession. In terms of the sacraments, the obligation of secrecy is imposed on secret marriages (can. 1131, $2^{\circ}$ and can. 1132 CIC as well as can. $840 \$ 1-3 \mathrm{CCEO}$ ). As far as administrative canon law is concerned, the obligation of secrecy is part of the procedure for appointing bishops (can. $377 \S 2$ and $3 \mathrm{CIC}$ as well as can. $184 \$ 1$ and can. $185 \$ 2$ CCEO), part of preparing lists of people who are suitable for episcopal office in case of an obstacle to the governance of the bishop's see (can. $413 \$ 1 \mathrm{CIC}$ ), and - as a requirement regarding secrecy of office - one of the duties of the members of the diocesan curia (can. 471, $2^{\circ} \mathrm{CIC}$ and can. $244 \$ 2,2^{\circ} \mathrm{CCEO}$ ). The obligation of secrecy entails the need to maintain a secret archive in every diocesan curia, where only the bishop is to have the key (can. $489 \$ 1-2$ and can. $490 \$ 1-3 \mathrm{CIC}$ as well as can. $259 \S 1-2$ and can. $260 \$ 1-3$

5 Codex Iuris Canonici auctoritate Joannis Pauli pp. II promulgatus of 25 January 1983, Acta Apostolicae Sedis [AAS] 1983, pars II, pp. 1-317.

6 Codex Canonum Ecclesiarum Orientalium auctoritate Joannis Pauli pp. II promulgatus of 18 October 1990, AAS 1990, No. 11, pp. 1045-1363.

7 More information may be found in Martens, K., Le secret dans la religion catholique, "Revue de Droit Canonique" 2002, No. 2, pp. 259-274; Coronelli, R., Significato ecclesiale del segreto, "Quaderni di Diritto Ecclesiale" 2013, No. 1, pp. 16-49; Waters, I., The law of secrecy in the Latin church, "The Canonist" 2016, No. 1, pp. 78-84; Rhode, U., Trasparenza e segreto nel diritto canonico, "Periodica de Re Canonica" 2018, No. 3, pp. 476-479. 
CCEO). At the central level, strict secrecy of the conclave, ${ }^{8}$ and the secrecy of office in force in the Roman Curia should also be mentioned. ${ }^{9}$

The area, where - according to canon law - secrecy must be strictly observed is the regulation of the Church's system of justice. Judges and tribunal personnel are always bound to observe secrecy of office in a penal trial, as well as in a contentious trial if the revelation of some procedural act could bring disadvantage to the parties (can. $1455 \$ 1 \mathrm{CIC}$ and can. $1113 \$ 1$ CCEO). They are also always bound to observe secrecy concerning the discussion among the judges in a collegiate tribunal (can. $1455 \$ 2$ CIC and can. $1113 \$ 2$ CCEO). Failure to observe secrecy is subject to canonical sanctions, including privation from office (can. $1457 \S 1$ and 2 CIC as well as can. $1115 \$ 1$ and 2 CCEO). If disclosure of the acts or evidence could endanger the reputation of others, provide opportunity for discord, or give rise to scandal or some other disadvantage, the judge can bind the witnesses, the experts, the parties, and their advocates or procurators by an oath to observe secrecy (can. $1455 \$ 3 \mathrm{CIC}$ and can. $1113 \$ 3 \mathrm{CCEO}$ ). Individuals bound to observe secrecy are exempted from the obligation to submit documents (can. $1546 \S 1$ CIC and can. $1227 \S 1$ CCEO) and to respond with respect to the information covered by the secrecy rule (can. $1548 \$ 2,1^{\circ} \mathrm{CIC}$ and can. $1229 \$ 2,1^{\circ} \mathrm{CCEO}$ ). Interestingly, canon law does not provide for the possibility for exemption from the obligation to observe secrecy of office by the court, as in the case of the national legal orders. The seal of confession is subject to special protection - a priest cannot be a witness with respect to any matters which they have come to know from sacramental confession, even if the penitent wishes them to be disclosed. Moreover, matters heard by anyone and in any way on the occasion of confession cannot be accepted even as an indication of the truth (can. $1550 \$ 2,2^{\circ} \mathrm{CIC}$ and can. $1231 \S 2,2^{\circ} \mathrm{CCEO}$ ). Nonetheless, the protection of secrecy goes beyond sacramentale sigillum, as clerics are exempted from the obligation to respond "to what has been made known to them by reason of sacred ministry" (can. $1548 \$ 2,1^{\circ} \mathrm{CIC}$ and can. $1229 \$ 2,1^{\circ} \mathrm{CCEO}$ ). Furthermore, can. $1548 \$ 2,2^{\circ} \mathrm{CIC}$ and can. $1229 \$ 2,2^{\circ} \mathrm{CCEO}$ also stipulate that

8 John Paul II, Apostolic Constitution Universi Dominici gregis of 22 February 1996, AAS 1996, No. 4, pp. 305-343, in particular No. 55-61. See also: Trevisan, G., Osservare il segreto secondo la costituzione "Universi Dominici Gregis», "Quaderni di Diritto Ecclesiale" 2009, No. 3, pp. 283-291; Majer, P., Secreto en la elección del Romano Pontífice, in: Otaduy, J. et al. (eds.), Diccionario General de Derecho Canónico, Vol. VII, Pamplona 2012, pp. 183-185.

9 In compliance with the General Regulations of the Roman Curia of 30 April 1999, all members of the Roman Curia shall observe secrecy of office, which is also supported by an oath taken to that effect. Violation of this oath shall result in suspension from office. See: Secretary of State, Regolamento Generale della Curia Romana, 30 April 1999, AAS 1999, No. 7, 629-699, Articles $18 \$ 2,36$ $\S 1,72,5^{\circ}$. 
all "those who fear that from their own testimony ill repute, dangerous hardships, or other grave evils will befall them, their spouses, or persons related to them by consanguinity or affinity" shall also be exempted from the obligation to respond.

In some cases, the obligation of secrecy entails an oath or promise, which, in canon law, has religious significance and constitutes open invocation of the divine name to solidify the promise to keep secret (can. $1199 \$ 1$ CIC and can. 895 CCEO).$^{10}$

According to Ulrich Rhode, the classification of the canon law provisions on the observance of secrecy may be presented as follows:

a) the provisions on the obligation to observe secrecy;

b) the provisions on the obligation to take an oath of secrecy;

c) the provisions on canonical sanctions for failure to observe secrecy;

d) the provisions governing storing, accessing, and deleting confidential documents;

e) the provisions that constitute the right to silence with respect to confidential information;

f) the provisions agreed with the state provisions as regards the observance of Church secrecy and the integrity of Church archives, also in compliance with secular legal norms. ${ }^{11}$

In the era of transparency, which involves technological development, the willingness to keep certain matters confidential raises suspicion. Even the very word "secret" is not widely accepted - it often evokes negative emotions and suggests ambiguous, clandestine activities which are supposedly dishonest. On the other hand, such terms as "openness" or "transparency" raise more positive feelings. If there is any part of life that must remain hidden from the public, the category of "privacy" seems more acceptable than "secret", as it shows that certain areas of human life shall be inaccessible, because people wish to keep them private. ${ }^{12}$ Despite tensions between the proposed transparency of actions and the need to keep some matters confidential, the Church stands for the protection of secrecy, mainly justifying this position with the dignity of the human being. The obligation of secrecy is firmly rooted in the need to protect the most intimate area of life. Every person has the right not to reveal those aspects of their life which they consider the most personal, intimate, and private. Every person also has the right to disclose

10 The aforementioned oath is required, for example, from people who hold Church offices (the Roman Curia and diocesan curia) and those who are to assume special functions or tasks (cardinal electors and others with access to the conclave or witnesses and parties testifying in Church procedures).

11 Rhode, U., op. cit., pp. 476-477.

12 See Montini, G.P., La Chiesa tra l'impegno per la trasparenza e la tutela del segreto, "Periodica de Re Canonica" 2018, No. 3, p. 538. 
such matters in a confidential manner - to open their souls and confess, to confide personal issues to other people, selected according to their own needs and in an absolutely free manner, being confident that the secrets will not be revealed. Both Church and secular laws safeguard such rights by specifying them and imposing administrative or penal sanctions in case of any infringement thereof, depending on the seriousness of each case for a single entity or community.

The right to secrecy and the protection of secrets are not limited to private welfare only, but also relate to the common good. The right is aimed at creating the chance to freely approach some people - not only private individuals, but also those selected on the basis of their public or social functions (doctors, lawyers, journalists, or priests) - with trust and confidence that one's privacy is duly protected. Therefore, by protecting the rights of individual entities, the Church or the state safeguard the so-called trust mechanism, which constitutes part of the common welfare. ${ }^{13}$ Moreover, ratio legis justifying the canonical regulation on the obligation of secrecy consists not only in the protection of the private good (the right to protection of reputation and integrity and the right to privacy $\left.{ }^{14}\right)$, but also to the common good - the freedom of authorities to make decisions (e.g. the election of the Pope, the appointment of bishops, or the resolution of court cases). Private interests are at times aligned with public interests (e.g. the purpose of secrecy in the procedure of appointing bishops is to protect both the freedom of exercising ecclesiastical powers and the personal good of the potential candidates - particularly those who shall not be eventually elected to the office of bishop)..$^{15}$ What is particularly significant is the obligation of secrecy in criminal proceedings, which shall be discussed in more detail in subsequent sections. It must be also remembered that, in some cases, the arguments justifying the obligation of secrecy may be in conflict with other rights and values - e.g. classifying evidence that may cause negative repercussions is against the right to defence, and closing the hearing to the public due to morality or security reasons is against the principle of transparency, which is one of the most fundamental guarantees of a fair trial. Therefore, the ecclesiastic significance of secrecy must include various factors and values, which are subject to protection and which coordinate the requirement of secrecy with other rights and interests. ${ }^{16}$

Therefore, the Church postulates that the right of secrecy established in the canonical legal order is also recognised and observed in the secular legal systems,

13 See: Martens, K., op. cit., p. 274.

14 See: can. 220 CIC and can. 23 CCEO.

15 See: Rhode, U., op. cit., pp. 479-481.

16 See: Coronelli, R., op. cit., pp. 52-53. 
mainly on the basis of non-admissibility as evidence, i.e. the prohibition against examining clerics as witnesses at court in the matter of their sacred ministry, the exemption from the obligation to report crimes, or the right to refuse to respond to any facts obtained by priests during confession. It is not uncommon to acknowledge and protect the seal of confession in secular law. ${ }^{17}$ However, faced with the scandal of priests sexually abusing minors, some state authorities have suggested or even officially put forward legislative initiatives - instituted in some countries aiming to revise the provisions in force so that sacramental secrecy is not protected in cases of sexual crimes against minors and a priest who obtains any information about such offences during confession is not exempted from the obligation to inform appropriate law enforcement authorities. ${ }^{18}$ The response to these demands was the Note on the importance of the internal forum and the inviolability of the

17 The laws applicable in that area within the European Union are described in: Robbers, G. (ed.), Państwo i Kościót w krajach Unii Europejskiej, Wrocław 2007, passim (original publication: State and Church in the European Union, Baden-Baden 2005). For Polish law, see: Rakoczy, B., Tajemnica spowiedzi w polskim postępowaniu cywilnym, karnym i administracyjnym, "Przegląd Sądowy" 2003, No. 11-12, pp. 126-138; Rutecki, M., Tajemnica spowiedzi a prawo człowieka do prywatności, in: Jasudowicz, T. et al. (eds.), Z problemów bezpieczeństwa. Prawa człowieka, Chojnice 2012, pp. 180-199; Pieron, B., Ochrona tajemnicy spowiedzi w prawie polskim, "Kieleckie Studia Teologiczne" 2012, No. 11, pp. 321-334; Adamczewski, K.K., Godność sakramentu pokuty a jego ochrona w prawie kanonicznym oraz w systemie prawa polskiego, "Łódzkie Studia Teologiczne” 2016, No. 2, pp. 16-21; Król, M., Niemożność bycia świadkiem w postępowaniu administracyjnym przez duchownego katolickiego w świetle Kodeksu postępowania administracyjnego i Kodeksu prawa kanonicznego z 1983 roku, "Acta Iuris Stetinensis" 2018, No. 3, pp. 129-142, DOI:10.18276/ ais.2018.23.07 (accessed 23.07.2020); Szymański, M., Tajemnica spowiedzi w prawie polskim - stan aktualny i propozycje zmian, "Internetowy Przegląd Prawniczy TBSP UJ" 2017, No. 4, pp. 73-85, http://www.tbsp.wpia.uj.edu.pl/documents/4137545/137185925/IPP_2017_4/acde991d-c3874e04-a9ee-e173bdd46bf\#page=73 (accessed 14.03.2020). For American and Canadian law, see: Jurzyk, M., Prawna ochrona tajemnicy spowiedzi w Stanach Zjednoczonych, "Studia z Prawa Wyznaniowego" 2001, No. 3, pp. 3-50; Zubacz, G.J., The sacramental seal of confession from the Canadian civil law perspective, doctoral dissertation, Saint Paul University, Ottawa 2008, https:// ruor.uottawa.ca/bitstream/10393/29803/1/NR52340.PDF (accessed 14.03.2020). To read more about the seal of confession according to Portugal law, see Lopes Almeida, J.J., O delito canonico e civil de violaçao do sigilo sacramental, "Revista Española de Derecho Canónico" 2006, No. 160, pp. 73-123. For Italian law, see: Boni, G., Sigillo sacramentale e segreto ministeriale. La tutela tra diritto canonico e diritto secolare, "Stato, Chiese e Pluralismo Confessionale. Rivista Telematica" 2019, No. 34, https://www.statoechiese.it/contributi/sigillo-sacramentale-e-segreto-ministeriale.la-tutela-ra-diritto-canonico (accessed 14.03.2020).

18 See: Mbwadiwe Osuala, T., Sigilo sacramental y denuncia obligatoria del abuso de menores. Una mirada global, "Revista Española de Derecho Canónico" 2019, No. 186, pp. 215-139; Palomino Lozano, R., Sigilo de confesión y abuso de menores, "Ius Canonicum" 2019, No. 118, pp. 778-804; Carní, M., Segreto confessionale e derive giurisdizionaliste nel rapporto della Royal Commission australiana, "Diritto e Religioni" 2019, No. 1, pp. 46-63. 
sacramental seal, dated 29 June 2019, from the Apostolic Penitentiary ${ }^{19}$ In this document, the Holy See reiterated the absolute integrity of the sacramental seal, which is based on the Law of God, without any exceptions.

The Church not only postulates the recognition and protection of the seal of confession in secular law, but also the acknowledgement of pastoral secrecy in the secular community, which is a type of professional secrecy of clerics, modelled on other professional groups. In some countries - sometimes as a result of the Concordat Agreement - the right of a priest to refuse to testify with information obtained while performing activities other than confession (e.g. spiritual direction or other spiritual advice subject to confidentiality, preparations for the sacrament of marriage, etc.) ${ }^{20}$ In other countries - e.g. in Poland - this right is not explicitly accepted and reference to a general professional secret is not always sufficient. Therefore, the legal scholars and commentators present well-founded postulates for changing this state of affairs. It is also worth mentioning that the postulates are not limited to only the Catholic Church, but refer to other churches and religious associations as well even those that do not have a formal ritual of confession. ${ }^{21}$

19 http://www.vatican.va/roman_curia/tribunals/apost_penit/documents/rc_trib_appen_ pro_20190629_forointerno_en.html (accessed 14.03.2020).

20 Examples of such guarantees in binding international agreements between the Holy See and states may be found in the concordats and arrangements made with Austria on 5.06.1933 (Article 18), Germany on 20.02.1933 (Article 9), Portugal on 7.05.1949 (Article 12), the Dominican Republic on 16.06.1954 (Article 11, sec. 2), Spain on 28.07.1976 (Article 2, sec. 2), Italy on 18.02.1984 (Article 4, sec. 4), Thuringia on 11.06.1997 (Article 2), Mecklenburg-West Pomerania on 15.09.1997 (Article 9), Saxony-Anhalt on 15.01.1998 (Article 1, sec. 3), and Slovakia on 24.11.2000 (Article 8, sec. 2). The texts of these international agreements are in: Lora, E. (ed.), Enchiridion dei concordati. Due secoli di storia dei rapporti Chiesa-Stato, Bologna 2003, pp. 854-855, 868869, 974-975, 1144-1145, 1492-1493, 1583, 1968-1969, 2014-2015, 2086-2087, 2216-2217. Furthermore, the rules on protecting information obtained while providing pastoral care services are included in the agreements signed with the following entities: the Free Hanseatic City of Bremen on 21.11.2003 (Article 9), Brazil on 13.11.2008 (Article 13), the Land of SchleswigHolstein on 9.12.2009 (Article 9), the Free and Hanseatic City of Hamburg on 6.07.2011 (Article 9), Equatorial Guinea on 13.10.2012 (Article 9, sec. 3), the Republic of Cape Verde on 10.06.2013 (Article 9, sec. 1), and the Democratic Republic of the Congo on 3.02.2017 (Article 9, sec. 2). The texts of the agreements published in AAS are also available online: https://www.iuscangreg.it/ accordi_santa_sede.php (accessed 14.03.2020).

21 See: Tomkiewicz, M., "Tajemnica spowiedzi" i "tajemnica duszpasterska" w procesie karnym, "Prokuratura i Prawo" 2012, No. 2, pp. 50-64; Pieron, B., Tajemnica zawodowa (duszpasterska) duchownego, "Annales Canonici" 2016, Vol. 12, pp. 131-153; Tomkiewicz, M., Czynności przeszukania w pomieszczeniach kościołów i innych związków wyznaniowych. Zatrzymanie dokumentów i innych rzeczy, "Annales Canonici" 2018, No. 1, pp. 137-139; Hucał, M., Tajemnica rozmowy duszpasterskiej na przykładzie Kościoła Ewangelicko-Augsburskiego - stan obecny i wnioski de lege ferenda, in: Zieliński, T. and Hucał, M. (eds.), Prawo do prywatności w Kościołach i innych związkach wyznaniowych. Od tajemnicy duszpasterskiej do ochrony danych osobowych, Warszawa 2019, pp. 250-259; Zamirski, K., Prawna ochrona tajemnicy duszpasterskiej a informacja o przestęstwie 


\section{Pontifical Secrecy}

Secretum pontificium constitutes a special type of secret in the canonical legal order. Even though it is not derived from the Law of God - unlike the seal of confession but from the Church's law, due to the fact that it refers to the Church's matters of greater significance, pontifical secrecy is considered a higher-ranking secret than the official secret binding all officials of the Roman Curia. ${ }^{22}$

The effective canonical regulation of the pontifical secrecy rule is included in the instruction Secreta continere of 4 February $1974 .{ }^{23}$ The institution stems from the former "Secret of the Holy Office," governed by the pontifical acts as of the $18^{\text {th }}$ century. ${ }^{24}$ Such a name was used to designate the present secretum pontificium until 1974. All members of the Congregation of the Holy Office (later also members of other dicasteries of the Roman Curia) were obliged to observe secrecy under oath; otherwise they risked excommunication latae sententiae (i.e. the punishment was implemented solely based on the illegal act itself, without the need to additionally impose it during the penal procedure), which - except for the risk of death - could only be lifted by the Pope. The Pope was also empowered to release someone from the obligation of secrecy.

The present name, secretum pontificium, explicitly indicates the Pope's responsibilities with respect to defining the obligation of secrecy and matters covered thereby. The secret is "pontifical," as it is regulated in a special manner by the Roman Bishop. First and foremost, it is binding upon their co-workers (inside or outside the Roman Curia) and refers to matters which concern the Pope or the Holy See or is directly related to the tasks performed upon the request of the Pope or for the

w percepcji wybranych polskich Kościołów mniejszościowych, in: Zieliński, T. and Hucał, M. (eds.), Warszawa 2019, pp. 269-282.

22 The differentiation between an "official secret" and a "pontifical secret" can be found in the General Regulations of the Roman Curia, where, according to Article $36 \$ 1$, an official secret should be duly observed, and according to Article $36 \$ 2$, the pontifical secrecy rule should be applied "with particular care". The consequences for violating official secrecy is disciplinary sanction in the form of temporary suspension from office (Article 72, $5^{\circ}$ ) and the violation of the pontifical secret is privation from office (Article $76 \$ 1,3^{\circ}$ ).

23 AAS, 1974, No. 2, 89-92. More information on pontifical secrecy can be found in: Arias, J., Las normas sobre el secreto pontificio. Sistema de defensa, "Ius Canonicum" 1974, No. 28, pp. 332-352; Perlasca, A., Il segreto pontificio, "Quaderni di Diritto Ecclesiale" 2013, No. 1, pp. 91-104; Laucirica, J.M., Secreto pontificio, in: Otaduy, J. et al. (eds.), Diccionario General de Derecho Canónico, Vol. VII, Pamplona 2012, pp. 186-189; de Paolis, V., El secreto pontificio: fundamento moral y jurídico, "Ius Communionis" 2018, No. 2, pp. 259-283.

24 The first legal regulation of the Secretum Sancti Officii was the decree of Pope Clement XI of 1 December 1709. For more on the history of pontifical secrecy see: Perlasca, A., op. cit., pp. 91-99; Rhode, U., op. cit., pp. 467-473; de Paolis, V., op. cit., pp. 271-273. 
benefit of the Pope. The instruction Secreta continere does not define or specify the pontifical secrecy rule, ${ }^{25}$ but indicates the scope of matters covered thereby as well as the categories of people to whom this rule applies.

In the decree from 1974 (Article 1), it is indicated that all Church matters of greater importance - the preparation of pontifical documents, some issues which are the responsibility of the Secretary of State, reports and proceedings in doctrinal cases and cases regarding crimes against faith, morality, and the sacrament of penance, reports drafted by papal legates, information obtained due to the office held about the appointment of important Church offices and positions (e.g. cardinals, bishops, papal legates, or officials of the Roman Curia), ciphers and ciphertext, or information and documents concerning legal or financial matters with respect to the Pope or the Secretary of State - are subject to the pontifical secrecy rule. ${ }^{26}$

As far as the subjective scope is concerned, Article 2 of the instruction Secreta continere includes the following categories of people obliged to observe the pontifical secrecy rule: cardinals, bishops, superiors, higher and lower ranking officials, advisers, and experts who deal with matters covered by pontifical secrecy; legates of the Holy See and diplomatic representatives, as well as all those who are contacted to express their opinion on matters covered by pontifical secrecy; people responsible for keeping pontifical secrecy while handling certain matters; as well as people who obtained some information that is subject to pontifical secrecy by chance or illegally.

The documents subject to the pontifical secrecy rule usually include the annotation sub secreto pontificio, therefore, everyone who - legally or illegally - comes into possession of such a document has a moral and legal obligation to observe secrecy, even if the person has not held any of the above-mentioned Church offices. The instruction Secreta continere includes canonical sanctions for breaching the secretum pontificium rule (Article $3 \mathrm{sec} .2$ ) - indeterminate penalties were provided for depending on the seriousness of the breach and losses caused, to be determined and imposed by a special committee of the dicasteries of the Roman Curia - yet, due to the fact that pursuant to can. 6 CIC all criminal laws in effect prior to the Code of Canon Law coming into force in 1983 were repealed, the instructions of the criminal provisions may not be applied. As mentioned above, ${ }^{27}$ the General Regulations

25 Apart from the general statement that 'those bound by papal secrecy have a serious obligation to observe it' (Article 3 sec. 1).

26 In the case of the last matter, the scope of the pontifical secret stipulated in the 1974 instruction was extended pursuant to rescriptum of the Secretary of State, De Regulis, quae ad Secretum Pontificium spectant of 5 December 2016, AAS 2017, No. 2, 72.

27 See: footnote 22. 
of the Roman Curia of 30 April 1999 include disciplinary sanctions for violating the pontifical secrecy rule. Furthermore, according to can. $1389 \$ 1$ CIC and can. 1464 $\$ 1$ CCEO, a person who abuses ecclesiastical power or an office, which applies to secretum pontificium and every official secret provided for under canon law, is to be punished with an indeterminate penalty. However, penal sanctions would be applicable on such grounds only when the infringer held any Church office or was commissioned with a particular task.

Secretum pontificium is not only a special type of official secret, but a separate category of secret. ${ }^{28}$ While the scope and manner of observing official secrecy are determined by the diocesan bishop (in the diocesan curia) ${ }^{29}$ and the doctrine states that a given person may, in certain serious and extraordinary circumstances, be released from the order of silence, ${ }^{30}$ in the case of pontifical secrecy, no possibility of exemption or dispensation thereof is explicitly provided for. ${ }^{31}$ Nonetheless, according to the text of the oath, which shall be taken by every person who, due to their function, handles matters covered by pontifical secrecy, it is apparent that the exemption from the obligation to observe secrecy may not be easily justified, since the pontifical secret may not be violated "in any manner, under any circumstances, either for greater good or to settle an urgent and serious matter," even after the issue subject to the pontifical secrecy rule has been handled (Article 4).

\section{Pontifical secrecy with respect to cases of sexual abuse of minors}

The instruction Secreta continere sets out an obligation to observe the pontifical secrecy rule with respect to any reports, proceedings, or decisions in moral cases. Such cases include sexual crimes committed by priests against minors. In compliance with can. $1395 \$ 2$ CIC, a cleric who has committed an offence against the Sixth Commandment, if the delict was perpetrated against a minor under the age of sixteen years, is to be punished with just penalties, not excluding dismissal from the clerical state if the case so warrants. The provisions of 21 May 2010 implemented by the Congregation for the Doctrine of the Faith with respect to more serious crimes,

28 See: de Paolis, V., op. cit., pp. 280-281; Laucirica, J.M., op. cit., p. 186. The opinion is justified by the fact that the official secret and pontifical secret are treated differently in Article 36 of the General Regulations of the Roman Curia.

29 See: can. $471,2^{\circ} \mathrm{CIC}$ and can. $244 \$ 2,2^{\circ} \mathrm{CCEO}$.

30 See: de Paolis, V., op. cit., pp. 268-270.

31 However, in compliance with the general legal principles, such as the $1^{\text {st }}$ Regula iuris by Pope Gregory IX ("Omnis res, per quascumque causas nascitur, per easdem dissolvitur" ["Everything that it is brought into being is dissolved again in the same way"]), the Holy See or, more precisely, the Secretary of State, may exempt someone from the obligation to observe secrecy. 
in which the recognition and punishment of an offender is under the jurisdiction of the Congregation, raised the minimum age of a passive victim to eighteen years, and made all minors equivalent to people who are incapable by reason of mental disorder. ${ }^{32}$ Moreover, the 'acquisition, possession, or distribution by a cleric of pornographic images of minors under the age of fourteen, for purposes of sexual gratification, by whatever means or using whatever technology' also constitutes a classified crime according to the Congregation for the Doctrine of the Faith. ${ }^{33}$ In fact, Article $30 \$ 1$ Normae de gravioribus delictis stipulates that "such matters are subject to pontifical secrecy." ${ }^{34}$

However, on the basis of the text of Article 1 sec. 4 of the 1974 instruction Secreta continere, it is not evident that the obligation of pontifical secrecy (secretum pontifcicium) in moral criminal cases is limited only to such cases that refer to classified crimes of the Congregation for the Doctrine of the Faith. The pontifical secrecy rule used to refer to every criminal procedure - from reports of a potential crime, through initial investigations and criminal proceedings (court or administrative), to the issuance of a judgement or decree closing the case ${ }^{35}$ - conducted in moral cases, i.e. a concubinage offence or other violation against the Sixth Commandment, committed by a priest with an adult, if the offence was public or violent. ${ }^{36} \mathrm{It}$ meant that the suspect, the accused, the victim, and any witnesses, attorneys and, obviously, representatives of the Church's legal system - judges, delegates of the bishop, notaries public, promoters of justice (prosecutors), interpreters, experts, etc. - were bound by strict confidentiality rules. ${ }^{37}$ All individuals admitted to the proceedings due to their functions were obliged to take an oath to respect pontifi-

32 Congregation for the Doctrine of the Faith, Normae de gravioribus delictis, AAS 2010, No. 7, p. 424, Article $6 \$ 1,1^{\circ}$.

33 Ibidem, Article $6 \$ 1,2^{\circ}$. According to the subsequent provisions promulgated by Pope Francis, the age of individuals shown in pornographic materials was raised to eighteen. See: the motu proprio Vos estis lux mundi of 7 May 2019, "L'Osservatore Romano" 10.5.2019, p. 10, Article $1 \S 2 . c$.

34 The same was stated in the previous - now repealed - provisions regulating the classified crimes of the Congregation for the Doctrine of the Faith included in the motu proprio of John Paul II, Sacramentorum sanctitatis tutela of 30 April 2001 along with the accompanying substantive legal provisions and procedural rules, Normae de gravioribus delictis. This motu proprio was the only official act promulgated at that time in AAS 2001, No. 11, pp. 737-739. The Normae were published unofficially in "Archiv für katholisches Kirchenrecht" 2002, No. 2, pp. 458-466.

35 See: Cito, D., Trasparenza e segreto nel diritto penale canonico, "Periodica de Re Canonica" 2018, No. 3, p. 520 .

36 See: can. $1395 \$ 1$ and 2 CIC.

37 "All persons who acquired knowledge of the case in a legitimate manner shall be bound by the secrecy rule." Cito, D., Norme «De gravioribus delictis». Commentario, in: del Pozzo, M. et al. (eds.), Norme procedurali canoniche commentate, Roma 2013, p. 654. 
cal secrecy, according to the text in the instruction Secreta continere, which reads as follows: "I am also aware that one who violates the secret commits a grave sin."

An order of confidentiality in this kind of criminal case does not seem to be illfounded. It is justified by the need to respect the reputation of a person who claims to have been harmed, i.e. the alleged injured party (the disclosure of whose identity and circumstances of a delict would cause more harm and entail further stigma) and the alleged offender (who shall enjoy the presumption of innocence until proven guilty), as well as any other people involved in the case (e.g. witnesses). ${ }^{38}$ The purpose of the secrecy is also to ensure smooth progress of the procedure - freedom of testimony for the witnesses, protection against corruption and attempts of exerting undue influence and external pressure (society, media, politics, etc.), and avoidance of prejudice and premature judgements. Another important function of the secret is that it protects against scandal. ${ }^{39}$

The same arguments justify closing the hearing to the public in common (secular) courts. Even though transparency is a constitutional principle according to Polish law (Article 45 sec. 1 of the Polish Constitution), some categories of cases may be, by virtue of law or upon the request of the parties, closed to the public - e.g. the court may close the hearing to the public completely or partially if it could violate good morals or private interests by being open ${ }^{40}-$ e.g. in the event the case concerns details of the parties' intimate sphere of life or drastic circumstances of events are the subject matter of the hearing.

Despite the above-mentioned arguments, applying the pontifical secrecy rule to canonical criminal proceedings against priests who commit sexual transgressions has provoked critical responses from both outside and inside the Church community. The most far-reaching accusations were those concerning the willingness to hide offenders despite certain regulations being in effect in some countries, according to which it is obligatory to inform law enforcement authorities that

38 According to can. $1717 \$ 1 \mathrm{CIC}$ and can. $1468 \$ 1 \mathrm{CCEO}$, an ordinary should "carefully" inquire a delict, and according to can. $1717 \$ 2$ CIC and can. $1468 \$ 2$ CCEO "care must be taken so that the good name of anyone is not endangered from this investigation". For the same reasons, in compliance with can. $489 \$ 2 \mathrm{CIC}$ and can. $259 \$ 2 \mathrm{CCEO}$, the documents of criminal cases concerning moral matters are to be kept safe in the archive of the curia and destroyed whenever the guilty parties die or ten years have elapsed since a condemnatory sentence concluded the affair. A short summary of the facts is to be kept, together with the text of the definitive judgement.

39 A scandal shall not be deemed to mean violation of somebody's sense of decency and willingness to maintain a good reputation of the institution of the Church externally despite the crimes committed by priests, but it shall be treated as a threat to the faith and morality of Christians. Therefore, the protection against scandal understood this way is one of the missions of the Church.

40 See: Article $360 \$ 1$ of the Polish Code of Criminal Procedure, Act of 6 June 1997, consolidated text: Dz.U. (Journal of Laws) 2020, item 30. 
a punishable offence has been committed. ${ }^{41}$ Pontifical secrecy makes impossible or significantly hinders practical cooperation between the Church, secular law enforcement authorities, and the justice system. This cooperation in prosecuting offenders of sexual crimes against minors was recommended in the circular letter of the Congregation for the Doctrine of the Faith of 3 May 2011 to assist episcopal conferences in developing guidelines for dealing with cases of clerics sexually abusing minors. ${ }^{42}$ Even though, according to the literature, pontifical secrecy does not limit the state's authority or release anyone from their obligation to reliably collaborate with secular bodies - since both the Church and the state are communities that stand in service of the good of entities and societies ${ }^{43}$ - in practice, it is difficult to reconcile the postulated "spirit of cooperation" with the formal observance of secrecy, especially when the law enforcement authorities ask the Church to disclose their documents of canonical proceedings that are subject to secretum pontificium; in the case of such discrepancies between the obligations resulting from the provisions of canon law and the orders of state law, commentators have recommended compliance with Church law. ${ }^{44}$

The obligation of secrecy entailed another inconvenience: the difficulty of providing information to Church authorities about a person who reports a suspected crime and/or alleged victim (not necessarily the same person), the course of the proceedings, decisions taken, and the final judgement in the case. It should be remembered that an injured party has no special rights in canonical proceedings - victims

41 Such obligation results, for example, from Article $240 \$ 1$ of the Criminal Code and Act of 6 June 1997, consolidated text: Dz.U. (Journal of Laws) 2019, item 2128. The position of the Church on the aforesaid obligation (also in other countries) is described in: Majer, P., Problem wykorzystywania seksualnego małoletnich w Kościele. Perspektywa prawnokanoniczna, in: Żak, A. and Kusz, E. (eds.), Seksualne wykorzystywanie małoletnich w Kościele. Problem - odpowiedź Kościoła - doświadczenie polskie, Kraków 2018, pp. 229-233.

42 AAS, 2011, No. 6, p. 408: "Sexual abuse of minors is not just a canonical delict but also a crime prosecuted by civil law. Although relations with civil authorities will differ in various countries, nevertheless it is important to cooperate with such an authority within their responsibilities. Specifically, without prejudice to the sacramental internal forum, the prescriptions of civil law regarding the reporting of such crimes to the designated authority should always be followed."

43 See e.g.: Cito, D., Trasparenza..., p. 521; Mosconi, M., I principali doveri del vescovo davanti alla notizia di un delitto "più grave» commesso contro la morale o nella celebrazione dei sacramenti, "Quaderni di Diritto Ecclesiale" 2012, No. 3, p. 307.

44 See: Bartone N., Il conflitto d’obbligo tra autorità ecclesiastica e autorità statale e il crimine di sesso del presbitero con il minore nella normativa comparata e interordinamentale, in: Questioni attuali di diritto penale canonico, Vaticano 2012, pp. 152-153; Nuñez, G., Abusos sexuales de menores. Consideraciones sobre el derecho de defensa y la colaboración con la autoridad civil, "Scripta Theologica" 2014, p. 756. 
are not treated as a party to the proceedings, but as a witness. ${ }^{45}$ Furthermore, in compliance with canon law, such a person is obliged - also under oath ${ }^{46}$ - to keep all contents of the investigation (questions and answers) confidential. The confidentiality obligation, even though justified by the above arguments, could indeed be construed as an attempt to disguise the truth. As a result, neither the person reporting the crime nor the alleged victim is given an opportunity to familiarise themselves with the course of the proceedings or the final decision in a legitimate manner. The same applies to the community of faith, in which a priest is accused of committing a crime and which should be informed about the punishment or acquittal of the accused priest. ${ }^{47}$

As a result of the critical comments and real obstacles created by the requirement to observe strict pontifical secrecy, it was proposed during the meeting of the chairpersons of the episcopal conference in Rome in February 2019 to relax the secrecy regulations so that -without prejudice to the protection of the values for the protection of which the secrecy rule was established (the dignity and reputation of people and the best interests of the Church) - it would be possible to create an environment of transparency and trust, while avoiding an impression that pontifical secrecy is used to hide problems. ${ }^{48}$

\section{Effects of lifting pontifical secrecy}

Even prior to the announcement of the decision to lift the pontifical secrecy rule in cases of sexual abuse of minors, Pope Francis introduced certain provisions on the protection of persons reporting a suspected criminal offence in his motu proprio

45 Only if the injured party brought a contentious action to repair damages incurred personally from the delict in a penal trial - not an administrative trial - pursuant to can. $1729 \$ 1 \mathrm{CIC}$ and can. $1483 \$ 1$ CCEO, would such injured party enjoy the rights of being a party to the proceedings.

46 The oath is not directly required under the instruction Secreta continere, but pursuant to can. 1455 $\$ 3$ CIC and can. $1113 \$ 3$ CCEO, "whenever the nature of the case or the evidence is such that disclosure of the acts or evidence will endanger the reputation of others, provide opportunity for discord, or give rise to scandal or some other disadvantage, the judge can bind the witnesses, the experts, the parties, and their advocates or procurators by oath to observe secrecy." Although according to the text of the above provision, it does not follow that the obligation to take the oath is absolute ("the judge can"), the nature of criminal cases of child sexual abuse turns such a possibility into an actual obligation.

47 See: Scicluna, C. and Tornelli, A., Scelta epocale che toglie ostacoli e impedimenti. Intervista con l'arcivescovo Scicluna, segretario aggiunto della Congregazione per la dottrina della fede, "L'Osservatore Romano" 18.12.2019, p. 4.

48 See Consapevolezza e purificazione. Atti dell'Incontro per la Tutela dei minori nella Chiesa (Città del Vaticano 21-24 febbraio 2019), Vaticano 2019, pp. 81, 94. 
Vos estis lux mundi of 7 May 2019. First of all, it should be stressed that the abovementioned reports do not constitute any infringement of official secrecy (Article 4 $\S 3)$. Any form of harming, repression, or discrimination due to filing such reports excluding false reports ${ }^{49}$ - shall be prohibited and considered an obstruction of the procedure, which is an illegal act (Article $4 \$ 2$ ). It is also prohibited to impose on the whistle-blower an obligation of silence with respect to the information included in the report of a suspected crime (Article $4 \S 3$ ).

Similar regulations are included in the Instruction on the confidentiality of legal proceedings of 6 December 2019, enclosed with the Rescriptum ex audientia pontificia published on the same date: ${ }^{50}$ "The person who files the report, the person who alleges to have been harmed, and the witnesses shall not be bound by any obligation of silence with regard to matters involving the case" (Article 5).

It should be mentioned that in the first document, the prohibition to impose the obligation of silence refers to the "contents of the report" and in the second one to "matters involving the case". Such expressions may be understood that it is prohibited to demand the observance of secrecy with respect to the events experienced by an alleged victim. The pontifical secrecy rule was often construed in a very strict manner and the victim was forbidden from speaking about being harmed. On the other hand it seems these expressions do not discount the possibility of imposing an obligation to keep secret the questions asked during criminal proceedings - or the initial investigation or hearing - and other circumstances about which an interviewee has already learnt in connection with the proceedings. It would not impose an obligation of secrecy with respect to an illegal act, but to circumstances whose disclosure could potentially disrupt or preclude cognisance of the case and the issuance of a fair decision. ${ }^{51}$

It seems that despite some doubts as to the effectiveness of can. $1455 \$ 3$ CIC and can. $1113 \$ 3 \mathrm{CCEO}$ (given the publication of the instructions), according to which the judge can bind the witnesses, the experts, the parties, and their advocates or procurators by oath to observe secrecy whenever the nature of the case or the evidence is such that disclosing the acts or evidence would endanger the reputation of others, provide opportunity for discord, or give rise to scandal or some other disadvantage, this canon cannot be invoked. Even though the instructions, as

49 By virtue of can. $1390 \$ 2$ CIC and can. 1454 CCEO, a person who calumniously denounces an offence commits a canonical crime.

50 See: footnote 2 .

51 Moreover, it is even possible to see a conflict between the provisions in Article 5 of the Instruction, where the obligation of secrecy is prohibited, and the provisions in Article 3 of the same legal act, according to which all persons involved in the proceedings shall observe official secrecy. 
executive legal acts, may not amend the laws - and if the instructions are contrary to the law (can. $34 \$ 2$ CIC) they are devoid of any legal effect - in this particular case, despite defining the document as "instructions," it is in fact an implementing act and, moreover, it includes a special clause introduced by the Pope which repeals any provisions that are incompatible therewith: contrariis quibuslibet, etiam speciali mentione dignis, minime obstantibus.

In compliance with the Instruction on the confidentiality of legal proceedings, the pontifical secrecy rule was lifted with respect to all reports, proceedings, and decisions regarding the crimes mentioned in Article 1 of the motu proprio Vos estis lux mundi of 7 May 2019 and Article 6 of Normae de gravioribus delictis, at the sole discretion of the Congregation for the Doctrine of the Faith, pursuant to the motu proprio Sacramentorum Sanctitatis Tutela by Saint John Paul II of 30 April 2001, as amended. Therefore, the above refers to the following crimes committed by clerics: 1) being involved in sexual activities with an under-aged or vulnerable person (i.e. a person who is unable to oppose aggression, even temporarily), 2) forcing someone into sexual activities - either by violence, threat, or abuse of power, 3) acquiring, storing, or distributing pornographic materials portraying minors under the age of eighteen years for obscene purposes, 4) involving a minor in pornographic performances, and 5) obstructing criminal proceedings against persons suspected of the aforementioned crimes by Church hierarchs.

The institution of pontifical secrecy has not been fully lifted and has not disappeared from the canonical legal order. The 1974 instruction Secreta continere is the legal act that remains in force, with recent amendments. The Pope's decision means that the Church authorities responsible for criminal proceedings related to the above-mentioned suspected crimes shall no longer be bound by pontifical secrecy. The same applies to individuals who report suspected crimes, injured parties, and witnesses testifying in canonical proceedings.

The decision does not mean that cases of crimes against the Sixth Commandment shall become public. Anyone who has become party to the procedure due to their function (judges, assessors, prosecutors, or notaries public) and anyone who gains knowledge of the subject matter of the proceedings or has been involved in the investigation shall be bound by official secrecy, the scope of which is to be determined by the provisions of law or the decision of the bishop. ${ }^{52}$ It is stressed in the

52 See: can. $471,2^{\circ} \mathrm{CIC}$ and can. $244 \$ 2,2^{\circ} \mathrm{CCEO}$ invoked in the Instruction and can. $1455 \$ 1$ CIC, as well as can. $1113 \$ 1$ CCEO. Even though, according to the text of can. $471,2^{\circ} \mathrm{CIC}$ and can. $244 \$ 2,2^{\circ}$ CCEO, official secrecy must be observed by persons holding office in the diocesan curia, the Secretary of the Pontifical Council for Legislative Texts stated that the regulation applies to all clerics and persons holding office in the Church, as well as to all parties involved in 
Instruction that information related to canonical proceedings shall only be used in a manner that guarantees its safety, integrity, and confidentiality so that the reputation, good image, and privacy of the parties to the proceedings are not damaged. The aforementioned principles refer not only to persons holding Church offices, but also to everyone who gains knowledge of the facts of the suspected crime.

The first comments after the new provisions came into force indicated that the Pope's decision constituted a response to the numerous appeals expressed during the summit devoted to the sexual abuse of minors which took place in February 2019. Andrea Tornielli, Editorial Director for the Vatican Dicastery for Communication, boldly referred to this decision as "historical" and defined it as "a sign of openness, readiness, transparency, and cooperation with secular authorities." ${ }^{53}$ Due to the ongoing difficulties and accusations that the Church is reluctant to collaborate with secular law enforcement authorities, the decision of Pope Francis means - according to the Italian journalist in the semi-official Vatican body - that the Church's documentation of criminal cases shall be made available to the secular authorities responsible for proceedings already covered by canonical proceedings.

Despite such positive opinions, the difficulties and doubts regarding the application of the Church's new provisions still persist. Such issues - to be discussed in the last section of this article - shall be resolved in the legal scholarship and commentary, practice, and case law.

\section{Questions regarding the new Church regulations}

The first potential difficulty in the Church cooperating with states in terms of sexual abuse crimes committed by clerics against minors is the differences in the understanding of such offences in the two legal orders. Canon law recognises an "offence against the Sixth Commandment" (can. $1395 \$ 2$ CIC) and an "external sin against chastity" (can. $1453 \$ 1 \mathrm{CCEO}$ ); thus, the act is prohibited by the law of God. It is rather too much to expect that secular law enforcement authorities become interested in prosecuting people who have transgressed the commandments of God. There are different types of criminal liability and different objective, subjective, and legal features of a criminal offence. ${ }^{54}$ Even though, according to Polish criminal

the proceedings in cases mentioned in the Instruction. See Arrieta, J.I., Riservatezza e dovere di denuncia, "L’Osservatore Romano" 18.12.2019, pp. 4-5.

53 Tornielli, A., Decisione storica. Frutto del summit di febbraio, "L'Osservatore Romano" 18.12.2019, p. 1.

54 More information about the differences between the legal regulations regarding sexual abuse crimes against minors in canonical and Polish legal orders may be found in: Skonieczny, P., 
law, every sexual offence involving a minor is also considered a canonical offence, not every such canonical offence is penalised under the Polish Criminal Code. For instance, such crimes prosecuted under canon law refer to individuals under eighteen years of age, whereas according to Articles 200 and 200(a) of the Polish Criminal Code they apply to individuals under fifteen years of age. Last but not least, the penal procedure provided for in each of such legal orders is also different. For example, prior to an interrogation, a witness in Church proceedings is not informed about any criminal liability for giving false testimony. Is it thus possible to invoke in secular proceedings, without any reservations, such witness's statements made before a Church authority? The witnesses in canonical proceedings take a religious oath to tell the truth. This raises the question of the witnesses' attitude towards their faith and religious practices in order to assess their credibility. Is it possible to provide secular law enforcement authorities with such information without any restrictions, while considering Article $53 \mathrm{sec} .7$ of the Polish Constitution: "No-one may be compelled by organs of public authority to disclose his philosophy of life, religious convictions, or belief?" Based on which criteria shall the secular prosecutor or court assess the potential differences between the testimony made by the same person in canonical proceedings and secular proceedings?

Therefore, it seems justified that secular law enforcement authorities or courts should demand that Church institutions document canonical proceedings in extenso. To respect the rights of people who testify in canonical proceedings, it would be appropriate to request that a given Church office provide certain information specified by the prosecutor's office or court - e.g. the decisions of Church authorities made with respect to the accused priest or a list of people who have already testified in canonical proceedings. In this case, the relevant state authorities could summon the same individuals and interrogate them in compliance with the rules of the criminal procedure under national law.

Article 4 of the Instruction on the confidentiality of legal proceedings of 6 December 2019 stipulates that official secrecy, which covers the information obtained during canonical proceedings, shall not prevent the fulfilment of any obligations resulting from secular laws effective in particular countries, including a potential obligation to report suspected crimes or to satisfy the requests of state judiciary

Przestępstwo cięższe przeciwko szóstemu przykazaniu Dekalogu z małoletnim - uwagi de lege lata $i$ de lege ferenda, "Prawo Kanoniczne" 2017, No. 1, 135-175; Skonieczny, P., Przestępstwo cięższe pornografii dziecięcej. Komentarz do art. $6 \$ 1$ n. 2 Sacramentorum sanctitatis tutela $z 2010 \mathrm{r}$., "Prawo Kanoniczne" 2017, No. 2, pp. 119-138. 
authorities. ${ }^{55}$ The argument behind such a provision is obvious: the official secrecy that must be observed according to canon law does not release someone from the obligation to report a suspected crime if the legislation of a given country imposes such an obligation. ${ }^{56} \mathrm{~A}$ similar situation exists in the case of a law of a given country that provides for the possibility to demand information or necessary documents or an expedient for the purpose of a fair judgement of the alleged offender. ${ }^{57}$

Nevertheless, the question arises whether the same obligation of disclosing the information to state authorities shall be binding upon Church institutions in the case of civil proceedings for damages. While the need for collaboration in criminal cases is justified for the purpose of finding the offender and bringing them to justice (after the accused's guilt has been proven), which is the aim of both the secular

55 The term "judiciary authorities" used in the Instruction does not preclude the acknowledgement of the same obligation with respect to a summons sent by law enforcement authorities, which are not judiciary authorities, for example, in the Polish legal system. The authors of the Instruction drew inspiration from the inquisitorial legal system existing in the Roman tradition, where the preliminary investigation falls within the competence of the judiciary.

56 For instance, this is the case with Polish legislation (Article 240 of the Criminal Code). Therefore, after the Act of 23 March 2017 on the amendment of the Criminal Code, the Juvenile Justice Act, and the Code of Criminal Procedure, Dz.U. (Journal of Laws) of 2017, item 773, came into force, the Conference of the Bishops of Poland amended, on 7 June 2017, the Guidelines for the preliminary canonical investigation in the case of accusations against a cleric for the transgression of the Sixth Commandment with a minor under the age of eighteen (Akta Konferencji Episkopatu Polski, 2017, No. 29, pp. 93-97). The recitals of this document stipulate that while examining the alleged misconduct of priests and adopting penal measures, Church authorities shall act "with respect for the national law of Poland". First, the reporting person shall be reminded about the obligation to notify the appropriate authorities of a prohibited act, and if they fail to do so, the Church authorities should advise the law enforcement authorities, unless those authorities have already been informed thereof.

57 In Article 2.5 of the guidelines Linee guida per i casi di abuso sessuale nei confronti di minori da parte di chierici (2012 and 2014 version), issued by the Conference of the Bishops of Italy; https:// www.chiesacattolica.it/documenti-segreteria/linee-guida-per-i-casi-di-abuso-sessuale-nei-confronti-dei-minori-da-parte-di-chierici (accessed 14.03.2020), the Conference of the Bishops of Italy stressed that bishops, who are not public officials according to Italian law, should be released from the obligation of denouncing priests and, pursuant to the concordat agreement guaranteeing the integrity of Church archives and the provisions of the Italian penal procedure, priests should be exempted from the obligation to testify with respect to what has been made known to them by reason of sacred ministry. However, after the latest amendment to the guidelines - Linee guida per la tutela dei minori e delle persone vulnerabili of 24 June 2019, https://www.chiesacattolica.it/ documenti-segreteria/linee-guida-per-la-tutela-dei-minori-e-delle-persone-vulnerabili (accessed 14.03.2020) - the above-mentioned provisions have been replaced by a general declaration of cooperation between the Church and the state authorities "in respect of mutual autonomy and canon, secular, and concordat law". It is also emphasised that reporting a crime does not exclude or hinder the procedure of notification of state authorities, but rather encourages such action. The canonical procedure is independent of the secular procedure, which it does not intend to replace (Article 5.6). 
and Church communities, in cases for damages, where the defendant is a Church legal person (e.g. a diocese), it is not so unequivocal. If, upon request of the court, the Church legal person disclosed an unfavourable document, such person would have to act against themselves. Even though the nemo tenetur se ipsum accusare principle - according to which there is no obligation to prove one's innocence or to provide evidence against oneself - usually refers to criminal law, it is sometimes used in civil proceedings as well. In such a case, nemo tenetur is expressed as nemo tenetur edere contra se or nemo tenetur se detegere (no-one is bound to arm his adversary against himself). However, even though this principle - according to the new civil procedure model, not only in the Polish legal order ${ }^{58}$ - seems to be less and less important than the judicial truth, ${ }^{59}$ it must be remembered that the nemo est principle is deeply rooted in the Constitution; thus, it is justified to limit knowledge of the truth in civil proceedings due to the need to safeguard other rights and values. ${ }^{60}$ It would be difficult to assume that the party to the litigation shall act to their detriment. Yet, on the other hand, to sustain the credibility of the Church - especially in such delicate matters as sexual abuse crimes against minors committed by priests - it is necessary to undertake common actions for the purpose of establishing the truth even at the expense of paying the compensation.

Last but not least, it should be determined whether the principle of reciprocity could be applied in this area and whether the Church judiciary could be provided with access to the materials used in prosecutorial or court proceedings. According to Polish law, third parties may examine the files pertaining to a court case or a preliminary investigation (during the pending proceedings). In the former case, the records may be made accessible to others with the consent of the president of the court (Article $156 \$ 1$ Code of Criminal Procedure) and in the latter case with the consent of the prosecutor (Article $156 \$ 5$ Code of Criminal Procedure). The consent to disclose the materials of a preliminary investigation may be granted optionally, in special circumstances if it is not necessary to safeguard the proper

58 Despite the fact that pursuant to Article $261 \S 2$ in connection with Article 304, the party may refuse to respond to the questions asked if their testimony could put them at risk of criminal liability, disgrace, or harmful direct material loss, in compliance with Article 3, the parties to the proceedings shall provide explanations with respect to the facts of the case, truthfully and accurately, and in compliance with Article $248 \$ 2$, the party may not refuse to produce a document upon request of the court if it may expose them to the risk of losing a case. See: Drozd, S., Prawo do żadania od przeciwnika wyjawienia niekorzystnych dla niego dowodów w polskim procesie cywilnym, http://www.codozasady.pl/prawo-do-zadania-od-przeciwnika-wyjawienia-niekorzystnychdla-niego-dowodow-w-polskim-procesie-cywilnym (accessed 14.03.2020).

60 See: Muliński, M., in: Góra-Błaszczykowska, A. (ed.), Kodeks postępowania cywilnego. Tom I A, Warszawa 2019, commentary to art. 3, p. 18, index 5. 
course of the proceedings or important interests of the state. One of the benefits derived from the information on the subject matter of a preliminary investigation carried out under canonical proceedings would be, for example, the possibility of abandoning the preliminary investigation in the diocese and notifying the Congregation for the Doctrine of the Faith about the allegations made against a priest. ${ }^{61}$ Similarly, by obtaining the testimony of a minor who is the alleged victim of a sexual abuse crime the re-interrogation of the same person could be avoided at the stage of the Church proceedings, which would be advantageous for the same reasons, based on which the Polish legislature decided that a person under the age of fifteen years may only be interrogated once (Article 185a $\$ 1$ Code of Criminal Procedure). Certainly, such a solution is aimed at mitigating the adverse effects of such situations on the mental well-being of a minor.

The cooperation between the Church and the state in terms of the prosecution, judgement, and fair punishment of priests who commit sexual crimes against minors is desirable and advantageous. Priests are subject to both the Church and secular legal order, so the punishment imposed in one legal system shall not replace the punishment in the other. ${ }^{62}$ Church law shall not replace penal legislation in countries where the Church is present, and shall not be used instead of the secular law, but rather next to it. The aforementioned crimes - despite their different legal configuration - shall be considered delicta mixta, which both the canonical and secular legal orders are trying to eliminate. To ensure successful collaboration in this area, it is essential to acknowledge the autonomy and independence of both legal systems, the differences in substantive law and procedures, and certain limitations resulting thereof. Whenever the state accepts the Church legal order, the Church jurisdiction referring to its affairs and independent Church judiciary authorities, ${ }^{63}$ the col-

61 According to can. $1717 \$ 1 \mathrm{CIC}$ and can. $1469 \$ 1 \mathrm{CCEO}$, an ordinary may completely abandon the idea of carrying out the preliminary investigation if such an inquiry seems entirely superfluous. Bearing in mind that the preliminary investigation is not aimed at proving guilt, but verifying the grounds for the report, if the information about the alleged crime is fully reliable and the facts of the case are evident - e.g. when the case is public and the accused priest has been arrested - the ordinary may immediately notify the Congregation for the Doctrine of the Faith, which shall be thenceforth responsible for the proceedings in the case.

62 However, it is also crucial to remember can. 1344 CIC and can. $1409 \$ 1$ CCEO, according to which the Church judge can, according to his own conscience and prudence, abstain from imposing a penalty, impose a lighter penalty, or employ a penance if the offender has reformed and repaired the scandal or if the offender has been or is foreseen to be punished sufficiently by the civil authority.

63 It might be the case in concordat states, where - pursuant to the international agreement with the Holy See - the state shall acknowledge final decisions of Church courts with respect to matrimonial matters, hence, accept the Church's judiciary power. Italy, Spain, Portugal, Malta, Croatia, Lithuania, and Slovakia are examples of such states. In Poland, even though the decisions of 
laboration may be beneficial. On the other hand, if the state continues to treat the Catholic Church only as a private institution or social or non-governmental organisation, and not a public law entity ${ }^{64}$ with its own legal system and judiciary power, as a consequence, it shall not acknowledge its autonomous jurisdiction (operating on its own) either, and instead of cooperating, the state will strive to subjugate the Church in a principled way, which - using the legally permitted instruments (property seizure or a call for the release or transfer of the seized property) - may cause the infringement of constitutional and international legal regulations governing the relationship between the Church and the state.

\section{References}

Adamczewski, K., Godność sakramentu pokuty a jego ochrona w prawie kanonicznym oraz w systemie prawa polskiego, "Eódzkie Studia Teologiczne" 2016, No. 2.

Arias, J., Las normas sobre el secreto pontificio. Sistema de defensa, "Ius Canonicum" 1974, No. 28.

Arrieta, J.I., Riservatezza e dovere di denuncia, “L’Osservatore Romano" 18.12.2019.

Bartone, N., Il conflitto d'obbligo tra autorità ecclesiastica e autorità statale e il crimine di sesso del presbitero con il minore nella normativa comparata e interordinamentale, in: Questioni attuali di diritto penale canonico, Vaticano 2012.

Boni, G., Sigillo sacramentale e segreto ministeriale. La tutela tra diritto canonico e diritto secolare, "Stato, Chiese e Pluralismo Confessionale. Rivista Telematica" 2019, No. 34.

Carní, M., Segreto confessionale e derive giurisdizionaliste nel rapporto della Royal Commission australiana, "Diritto e Religioni" 2019, No. 1.

Cito, D., Norme «De gravioribus delictis». Commentario, in: del Pozzo, M. et al. (eds.), Norme procedurali canoniche commentate, Roma 2013.

Cito, D., Trasparenza e segreto nel diritto penale canonico, "Periodica de Re Canonica" 2018, No. 3.

Consapevolezza e purificazione. Atti dell'Incontro per la Tutela dei minori nella Chiesa (Città del Vaticano 21-24 febbraio 2019), Vaticano 2019.

Coronelli, R., Significato ecclesiale del segreto, "Quaderni di Diritto Ecclesiale" 2013, No. 1.

de Paolis, V., El secreto pontificio: fundamento moral y jurídico, "Ius Communionis" 2018, No. 2.

Church courts are not respected by the state under Article $10 \mathrm{sec}$. 3-5 of the Concordat between the Holy See and the Republic of Poland of 28 July 1993, Dz.U. (Journal of Laws) 1998, No. 51, item 318, the Church's jurisdiction is still acknowledged.

64 See: Dobkowski, J., Status administracyjno-prawny Kościoła Katolickiego w Polsce (przyczynek do dyskusji), “Civitas et Lex” 2017, No. 1, pp. 21-28. 
Dobkowski, J., Status administracyjno-prawny Kościoła Katolickiego w Polsce (przyczynek do dyskusji), "Civitas et Lex" 2017, No. 1.

Drozd, S., Prawo do żądania od przeciwnika wyjawienia niekorzystnych dla niego dowodów w polskim procesie cywilnym, 7.09.2017, Co do zasady, http://www.codozasady. $\mathrm{pl}$ /prawo-do-zadania-od-przeciwnika-wyjawienia-niekorzystnych-dla-niego-dowo dow-w-polskim-procesie-cywilnym.

Gradi, M., L'obbligo di verità delle parti, Torino 2018.

Hucał, M., Tajemnica rozmowy duszpasterskiej na przykładzie Kościoła Ewangelicko--Augsburskiego - stan obecny i wnioski de lege ferenda, in: Zieliński, T. and Hucał, M. (eds.), Prawo do prywatności w Kościołach i innych związkach wyznaniowych. Od tajemnicy duszpasterskiej do ochrony danych osobowych, Warszawa 2019.

Jurzyk, M., Prawna ochrona tajemnicy spowiedzi w Stanach Zjednoczonych, "Studia z Prawa Wyznaniowego" 2001, Vol. 3.

Król, M., Niemożność bycia świadkiem w postępowaniu administracyjnym przez duchownego katolickiego w świetle Kodeksu postępowania administracyjnego i Kodeksu prawa kanonicznego z 1983 roku, "Acta Iuris Stetinensis" 2018, No. 3.

Laucirica, J.M., Secreto pontificio, in: Otaduy, J. et al. (eds.), Diccionario General de Derecho Canónico, vol. VII, Pamplona 2012.

Lopes Almeida, J.J., O delito canonico e civil de violaçao do sigilo sacramental, "Revista Española de Derecho Canónico” 2006, No. 160.

Lora, E. (ed.), Enchiridion dei concordati. Due secoli di storia dei rapporti Chiesa-Stato, Bologna 2003.

Majer, P., Problem wykorzystywania seksualnego małoletnich w Kościele. Perspektywa prawnokanoniczna, in: Żak, A. and Kusz, E. (eds.), Seksualne wykorzystywanie małoletnich w Kościele. Problem - odpowiedź Kościoła - doświadczenie polskie, Kraków 2018.

Majer, P., Secreto en la elección del Romano Pontífice, in: Otaduy, J. et al. (eds.), Diccionario General de Derecho Canónico, vol. VII, Pamplona 2012.

Martens, K., Le secret dans la religion catholique, "Revue de Droit Canonique" 2002, No. 2.

Mbwadiwe Osuala, T., Sigilo sacramental y denuncia obligatoria del abuso de menores. Una mirada global, "Revista Española de Derecho Canónico” 2019, No. 186.

Montini, G.P., La Chiesa tra l'impegno per la trasparenza e la tutela del segreto, "Periodica de Re Canonica" 2018, No. 3.

Mosconi, M., I principali doveri del vescovo davanti alla notizia di un delitto "più grave» commesso contro la morale o nella celebrazione dei sacramenti, "Quaderni di Diritto Ecclesiale" 2012, No. 3.

Muliński, M., in: Góra-Błaszczykowska, A. (ed.), Kodeks postępowania cywilnego. Tom I A, Warszawa 2019.

Nuñez, G., Abusos sexuales de menores. Consideraciones sobre el derecho de defensa y la colaboración con la autoridad civil, "Scripta Theologica" 2014, Vol. 46. 
Padovese, L., Segreto, in: Compagnoni, F. et al. (eds.), Nuovo dizionario di teologia morale, Cinisello Balsamo 1990.

Palazzini, P., Secretum, in: Palazzini, P., Dictionarium morale et canonicum, Vol. IV, Roma 1968.

Palomino Lozano, R., Sigilo de confesión y abuso de menores, "Ius Canonicum” 2019, No. 118.

Perlasca, A., Il segreto pontificio, "Quaderni di Diritto Ecclesiale” 2013, no. 1.

Pieron, B., Ochrona tajemnicy spowiedzi w prawie polskim, "Kieleckie Studia Teologiczne" 2012, No. 11.

Pieron, B., Tajemnica zawodowa (duszpasterska) duchownego, "Annales Canonici” 2016, Vol. 12.

Rakoczy, B., Tajemnica spowiedzi w polskim postępowaniu cywilnym, karnym i administracyjnym, "Przegląd Sądowy" 2003, No. 11-12.

Rhode, U., Trasparenza e segreto nel diritto canonico, "Periodica de Re Canonica" 2018, No. 3.

Robbers, G. (ed.), Państwo i Kościót w krajach Unii Europejskiej, Wrocław 2007.

Rutecki, M., Tajemnica spowiedzi a prawo człowieka do prywatności, in: Jasudowicz, T. et al. (eds.), Z problemów bezpieczeństwa. Prawa człowieka, Chojnice 2012.

Scicluna, C. and Tornielli, A., Scelta epocale che toglie ostacoli e impedimenti. Intervista con l'arcivescovo Scicluna, segretario aggiunto della Congregazione per la dottrina della fede, "L'Osservatore Romano" 18.12.2019.

Skonieczny, P., Przestępstwo cięższe pornografii dziecięcej. Komentarz do art. $6 \$ 1$ n. 2 Sacramentorum sanctitatis tutela $z 2010$ r., "Prawo Kanoniczne" 2017, No. 2.

Skonieczny, P., Przestępstwo cięższe przeciwko szóstemu przykazaniu Dekalogu z małoletnim - uwagi de lege lata i de lege ferenda, "Prawo Kanoniczne" 2017, No. 1.

Szymański, M., Tajemnica spowiedzi w prawie polskim - stan aktualny i propozycje zmian, “Internetowy Przegląd Prawniczy TBSP UJ” 2017, No. 4, http://www.tbsp.wpia.uj.edu. pl/documents/4137545/137185925/IPP_2017_4/acde991d-c387-4e04-a9ee-fe173bd$\mathrm{d} 46 \mathrm{bf} \#$ page $=73$.

Tomkiewicz, M., “Tajemnica spowiedzi” i "tajemnica duszpasterska” w procesie karnym, "Prokuratura i Prawo" 2012, No. 2.

Tomkiewicz, M., Czynności przeszukania w pomieszczeniach kościołów i innych związków wyznaniowych. Zatrzymanie dokumentów i innych rzeczy, "Annales Canonici" 2018, No. 1.

Tornielli, A., Decisione storica. Frutto del summit di febbraio, "L’Osservatore Romano" 18.12.2019.

Trevisan, G., Osservare il segreto secondo la costituzione «Universi Dominici Gregis», "Quaderni di Diritto Ecclesiale" 2009, No. 3.

Waters, I., The law of secrecy in the Latin church, “The Canonist” 2016, No. 1. 
Zamirski, K., Prawna ochrona tajemnicy duszpasterskiej a informacja o przestępstwie w percepcji wybranych polskich Kościołów mniejszościowych, in: Zieliński, T. and Hucał, M. (eds.), Prawo do prywatności w Kościołach i innych związkach wyznaniowych. Od tajemnicy duszpasterskiej do ochrony danych osobowych, Warszawa 2019.

Zubacz, G.J., The sacramental seal of confession from the Canadian civil law perspective, doctoral dissertation, Saint Paul University, Ottawa 2008.

\section{CITATION}

MAJER, P., The lifting of "pontifical secrecy" and the relationship between the state and Church systems of justice in the subject matter of sex offences against minors, "Acta Iuris Stetinensis" 2020, No. 1 (Vol. 29), 101-126, DOI: 10.18276/ais.2020.29-08. 